\title{
The Post COVID-19 World: Efforts Needed to Build Back a More Resilient Society
}

\author{
Keerthan $\operatorname{Raj}^{1} \&$ P. S. Aithal ${ }^{2}$ \\ College of Management \& Commerce, Srinivas University, Mangalore - 575 001, India. \\ ${ }^{1}$ OrchidID:0000-0003-0190-4610, E-mail:2keerthanraji@gmail.com \\ ${ }^{2}$ Orchid ID: 0000- 0002-4691-8736, E-mail: psaithal@gmail.com
}

Area of the Paper: Management.

Type of the Paper: Research Analysis.

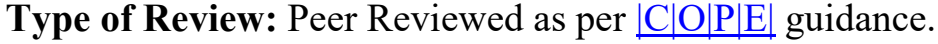

Indexed In: OpenAIRE.

DOI: http://doi.org/10.5281/zenodo.3783563.

Google Scholar Citation: IJCSBE.

\section{How to Cite this Paper:}

Raj, K., \& Aithal, P. S. (2020). The Post COVID-19 World: Efforts Needed to Build Back a More Resilient Society. International Journal of Case Studies in Business, IT, and Education (IJCSBE), 4(1), 88-93. DOI: http://doi.org/10.5281/zenodo.3783563.

International Journal of Case Studies in Business, IT and Education (IJCSBE)

A Refereed International Journal of Srinivas University, India.

(C) With Authors.

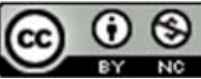

This work is licensed under a Creative Commons Attribution-Non-Commercial 4.0 International License subject to proper citation to the publication source of the work.

Disclaimer: The scholarly papers as reviewed and published by the Srinivas Publications (S.P.), India are the views and opinions of their respective authors and are not the views or opinions of the S.P. The S.P. disclaims of any harm or loss caused due to the published content to any party. 


\title{
The Post COVID-19 World: Efforts Needed to Build Back a More Resilient Society
}

\author{
Keerthan Raj ${ }^{1} \&$ P. S. Aithal ${ }^{2}$ \\ College of Management \& Commerce, Srinivas University, Mangalore - 575 001, India. \\ ${ }^{1}$ OrchidID:0000-0003-0190-4610, E-mail:2keerthanraji@gmail.com \\ ${ }^{2}$ Orchid ID: 0000- 0002-4691-8736, E-mail: psaithal@gmail.com
}

\begin{abstract}
The first half of the year 2020 will be well remembered and recollected by historians, researchers, thinkers over the years for the disruption caused the world over by the corona virus pandemic. The largest economies of the world were on lockdown to contain the virus. It pitted the whole of humanity against the virus. There has been severe irretraceable damage to economic and human health, wealth and prosperity. These histories of pandemics that have amputated nations over the years have also seen different measures that have been taken up to arrest the spread of the pandemics. Some of these measures are isolation, quarantine, confinement and more significantly nationwide or region wise lockdown. These measures have a severe impact on the social, political and economic facets of the nation/nations. Post COVID-19 there will be a lot of lessons to learn and pick up from and the impact this virus and measures are taken to contain its spread has had on the nation. This paper is intended to look at living communities and some important dimensions that we believe need attention to create a minimally disruptive ecosystem to sustain such pandemics in the near future.
\end{abstract}

Keywords: Coronavirus, Economy, Pandemic.

\section{INTRODUCTION :}

The Coronavirus pandemic which initially evoked a lukewarm response as something happening in another nation, over a matter of a few days shook up the entire world in so many ways. From disrupting routine lifestyle, havocking livelihoods of many, ravaging businesses, disrupting economic growth it set back the world for many years. While nations are trying hard to find cures and vaccines, and countries are only finding a solution in the oldest form of disease prevention - 'staying away from each other', isolation, quarantine being the only solution available to governments. The World Health Organization, named the coronavirus a 'pandemic' on March 11, 2020, basically, in an attempt to warn other nations of the impending dangers.

Pandemic defined: A pandemic is defined as "a global outbreak of a disease" [1]. Pandemics are generally classified as epidemics first, which spreads across a region, like the Ebola virus (Africa), COVID-19 began as an epidemic in China and then made its way across the world in a matter of a few weeks thus making it a pandemic.

Global Pandemics in the $21^{\text {st }}$ century -

Influenza Virus: The modern industrial age from 1889-1890 saw the rise and spread of the influenza viruses which created quite a havoc. This influenza spread across the globe and killed 1 million people. It started in Russia and spread through Europe and the rest of the world, this is a time when air travel did not exist.

Polio Epidemic: The world was shaken by the polio epidemic in 1916 that started in New York, though not a pandemic, it occurred sporadically in the United States and parts of the world.

Spanish Flu: During 1918-1920around 500 million people were struck by the Spanish flu. Also beleaguered by World War I, it claimed lives and cramped the wellbeing of society.

Asian Flu: Another pandemic with its roots in China, the Asian Flu claimed more than 1 million lives between 1957-58. And this pandemic spread across the world similar to the COVID 19 we see today. 
AIDS Pandemic and Epidemic: Since it was first identified in 1981 an estimated 35 million lives have been lost to the AIDS virus known to have been developed from a chimpanzee virus that transferred to humans in West Africa in the 1920s.

H1N1 Swine Flu: The Swine Flu Pandemic from 2009-10 was caused by a new strain of H1N1 originated in Mexico in 2009 before spreading to the rest of the world. In one year, the virus infected 1.4 billion people and many lives were lost.

West African Ebola Epidemic: Ebola ravaged West Africa from 2014-2016 and still has no cure [2]. The COVID-19 is an addition to the list of pandemics and epidemics but of recent past, it has affected economies severely because of the lockdowns imposed by most governments across the world.

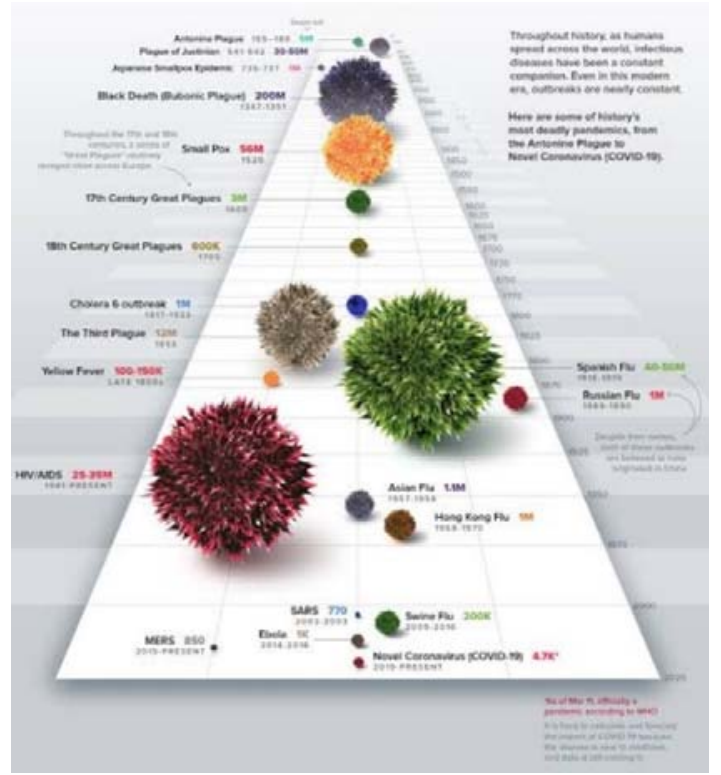

Fig. 1 : History of Pandemics (Source : Visual Capitalist, 2020 [3])

Significant measures have been witnessed over the years to contain the spread of epidemics and pandemics - these take the form of isolation, containment, quarantine and region or national lockdowns. Each outbreak is accompanied by the implementation of health regulations for containment. This picture of a diseased person often justifies the moral, societal and economic imperatives of defending a healthy nation from those afflicted by the disease. In the earlier days, quarantine measures helped to promote overseas commercial trade and helped thinkers stress on public welfare measures to shape future societies. Nations have serious questions on either using successful containment measures by isolation, quarantine, tracing exposed individuals, vaccinating, decontaminating places and things as well as the far-reaching nationwide lockdowns. This against pitting its healthy population to expose themselves to the virus and develop "herd immunity" down the years which will, in turn, happen at the loss of many lives. This again is a thinking that balances the weak and fragile to the survival of the strong and immune population. The choice is with the governance to decide on wither course of action whilst considering the socio-economic impact measures like lockdowns will have.

\section{THE CHANGING SCENARIO :}

At the beginning of 2020, the Economic Survey released a day before the Union Budget had projected a GDP growth of $6-6.5$ percent but since has been reduced to slow down to $4.6-4.8$ percent in the current fiscal 2020-21. However, as of March mid itself due to the requirement of lockdown, the World Bank and credit rating agencies have downgraded India's growth for the fiscal year 2021 with the lowest figures India has witnessed since the last three decades. The International Monetary Fund further slashed India's growth estimate for FY 21 to 1.9\% from 5.8\%estimated in January warning that the worst recession since the Great Depression will have far reaching impact. But the bright side is they expected India and China would be the only two major economies likely to register growth and al others would contract. The COVID-19 pandemics is expected to shrink world output by $3 \%$ in 2020 . 
The lockdown has led to the 140 million jobs being lost and $45 \%$ of households reported an income drop. Under complete lockdown less than a quarter of India's \$2.8 trillion economy is functional. 53\% of businesses are affected and this has led to disruption in businesses across sectors. The agriculture sector, manufacturing sector, automotive sector, tertiary sector, services sectors all have had major expectations in business and this will lead to disruption in value chains. In the short term of 6-8 months estimating demand will be very difficult and businesses will be embroiled in unpredictability. The Indian economy is estimated to lose over 32,000 crore (US $\$ 4.5$ billion) every day. There is an economic cost that has to be paid to reduce the infection rate. It is not just reflected by government policies restricting activities and movement but self-inflicted measures by people at large. People change their behaviour. Most would choose not to visit restaurants, or take trips. Once this happens having a strong economy of a previous year is never and option. It would set back the growth trajectory by a few inches back.

\section{KEY PRIORITIES IDENTIFIED TO BUILD BACK A BETTER RESILIENT SOCIETY POST COVID :}

The immediate key priority post COVID-19 would be as identified by us could be classified into three areas. If strategic changes could be brought about in these three areas the post COVID world would be able to rise to higher economic progress with least disruption future pandemics.

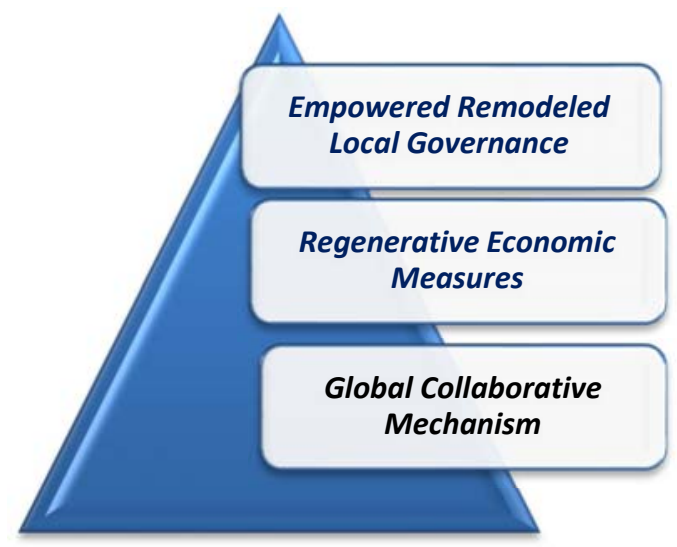

Fig. 2: Post COVID World Priority Areas

\section{(1) Empowered Remodeled Local Governance:}

In order to face any epidemic or pandemic, in the first instance, there needs to be strong local governance at the lowest level of the administrative wing. The local government should be empowered with decentralized decision making and measures to act fast. The major bottleneck in a highly populated nation such as India is the fact that urban living spaces are highly overburdened with the typography and morphology. There is a mass exodus of people from rural and semi-rural areas moving in to make a living in large cities. When planning cities this migrant working population needs to be considered to create dwelling spaces, ample sanitation and hygiene education to this population. In times of such viral infection spreads most quickly in these mass human settlements since the hygiene, sanitation and education levels are poor. It is not possible to educate them later once during a fullblown infection spread, the containment measures become very difficult to implement. Most governances tend to look at immediate problems and overlook the need for a strategic vision for the future. Disruptive changes should pave the way for remodeled ways of administration and implementation. The empowerment and remodeled local governance should cover the following aspects -

A road map for managing urban settlements growth and morphology of urban development and its readiness for a changed scenario Migratory worker population dwelling and settlement plans. An emergent model should look at and provide for grass root level empowerment in 7 sources of change 
and change enablers - education, infrastructure, public health, demographics, urban morphology, environment and technology.

\section{(2) Regenerative Economic Measure:}

The COVID 19 pandemic and the associated measures to check its spread has pinned back the economy by significant points. During the pandemic crisis of 2020, three of the eight billion people on the planet were in the grip of an unprecedented lockdown. Global travel and stopped completely and supply chains disrupted. What will be needed in the post COVID world would be large scale coordinated and comprehensive multilateral resources to pull the businesses and people out of economic deprivation and shortages. Welfare measures should address household income disruptions of the people especially the bottom of the pyramid, vulnerable class. More support to businesses in the unorganized sector and micro small and medium enterprises which is the backbone of employment generation in the country needs to be addressed with direct support and guarantees. Businesses will be facing a severe liquidity crunch, uncertainty in demand and hence production supply chain disruptions, a major rethinking on building a model to redefine business goals, processes, products and services is the new order of the day. The new model has to be created and built around newer ways of doing business and they will need to rebound with strategies to be able to run businesses in an agile environment in the future. Economic measures should be decisive, innovative and address the socio-economic devastation that the nations have locked themselves into to contain the virus. India needs to address diverse sectors in certain sectors that have been affected more than others are aviation and tourism, non-essential goods manufacturing, discretionary consumer consumption items, oil and gas. Rather than just looking at measures to cover the holes created by the lockdown, this would be an opportunity to divert attention and resources to needed sectors and build a more diverse and resilient economy. Even for external global investors, it has to seem attractive, globally the majority of businesses have faced disruptions and economic fallout, they would be looking to move to newer and value propositions and to countries that can provide a socio-economic fabric that is more sustainable, agile, resilient and dynamic.

\section{(3) Global Collaborative Mechanism:}

The third and fundamentally very important aspect needed to be worked on at a war footing is a globally collaborative mechanism of nations. COVID 19 has been a unifier of sorts by having impacted such a large number of countries and still counting. While some African sub Saharan nations do not have adequate funding to tide over this pandemic, the G 20 countries have agreed to succor weaker nations. At least the larger economies need to work together at a gigantic level to fulfill the following parameters

- To take forward the Biological Weapons Convention to further curb the use of and spread of such biological quasi cross border movement of biological arms. Similarly, other global governance institutions such as the United Nations will need to step in to equip all nations with the efficiency and agility to respond swiftly to global challenges.

- Global collaborative agreements and conventions need to put in place mechanisms to make countries and institutions accountable for practices, deliberately or otherwise, which are a risk to humanity and which test the resilience of national health care systems. Global collaboration is also needed on a unified globally shareable healthcare system in times of dire distress.

- International organizations should strive to create safety nets for the most vulnerable sectors of the society because post COVID the ugly underbelly of such segments will be heavily exposed which would nose dive economies into a severe recession. Further, global collaboration is the immediate requisite since nations will be reeling for financial aid as developed counties could assist those less developed to boost their health systems and the response capacity to stop transmission.

- All nations have to come together post this to tackle the profound consequences of this pandemic. Though this is, as discussed above not the world's first modern pandemic, it is impacting nations because of the measures needed to be taken to contain it and economies are emerging over to larger stages of growth, the larger the range, the higher would be the intensity of the impact.

- It is also different than earlier pandemics because it is truly universal with known cases in 196 countries and territories across the world. Global solidarity in addressing the waterfall arising post COVID is the need of the hour. Most countries are slowly reaching the tail of the infection spread and see light at the end of the tunnel. On the fiscal front, increasing resources available to developing 
countries by expanding the borrowing capacities, could inject fresh flow into the system, swaps among central banks could ease liquidity crunch and debt alleviation should be addressed by partial loan waivers.

The recovery post COVID would definitely lead to significant changes in the economy, even from simple habits people may follow to look at efforts to being more hygiene in simple respiratory hygiene, sanitization, lesser travel, etc may be a norm for some time and social distancing would lead to a different subset of societal social, cultural practices. The use of technology should be at its optimum level to maintain social distancing in the working area in all industries and to avoid unnecessary social gathering as an alternative strategy [4].

\section{CONCLUSION :}

As the world is already seeing a plateauing off in COVID cases, there is a sigh of relief in many countries, the coronavirus has brought about and will bring about changes in day to day lifestyles of people, and change the normal order. Most organizations and businesses and nations will be strategizing, prioritizing and reassembling their arsenal to remodel their way of functioning. This is also where our earlier proposed cockroach theory of scalability and sustainability is going to draw importance, it proposes a four key component model to reshape businesses to help them stay afloat grow- scale - strengthen. Like the cockroach which reemerges even after a nuclear war, such pandemics will be a routine feature in the coming years. As mentioned earlier, nations need to build themselves in the three priorities discussed above and using the components mentioned in the cockroach theory reassess and rethink and redefine themselves to sustain and scale $[5,6]$. The only way to survive and sustain is to be alert and agile.

\section{REFERENCES :}

[1] Phin, N. F. (2011). Living forwards, understanding backwards. Bulletin of the World Health Organization, 89, 541-542.

[2] Huremovic, D. (2019). Brief History of Pandemics (Pandemics Throughout History). In Psychiatry of Pandemics (pp. 7-35). Springer, Cham.

[3] https://www.visualcapitalist.com/history-of-pandemics-deadliest/ referred on 01/05/2020.

[4] Aithal P. S. \& Architha Aithal (2018). The Concept and Importance of Alternative Strategy as Parallel Strategy to be followed in Organizational Decisions to Ensure Success. International Journal of Management, Technology, and Social Sciences (IJMTS), 3(2), 1-15. DOI : http://doi.org/10.5281/zenodo.1302779.

[5] Raj, K., \& Aithal, P. S. (2018). Cockroach Theory of Organizational Sustainability and Scalability: Detailed Study on Evidence Based on BOP Approach. IRA-International Journal of Management \& Social Sciences, 12(1), 1-11. DOI: http://doi.org/10.21013/jmss.v12.n1.p1.

[6] Raj, K., \& Aithal, P. S. (2018). The Cockroach Theory for Sustainable and Scalable Organizational and Individual Growth. International Journal of Advanced Trends in Engineering and Technology, 3(1), 146-149. DOI: http://doi.org/10.5281/zenodo.1237899.

$* * * * * * * * * * * *$ 